\title{
The In Vivo Selection Method in Breast Cancer Metastasis
}

\author{
Jun Nakayama ${ }^{1, * \mathbb{D}}$, Yuxuan Han ${ }^{2}$, Yuka Kuroiwa ${ }^{1,2}$, Kazushi Azuma ${ }^{2}$, Yusuke Yamamoto ${ }^{1}$ and \\ Kentaro Semba ${ }^{2,3}$
}

Citation: Nakayama, J.; Han, Y.;

Kuroiwa, Y.; Azuma, K.; Yamamoto Y.; Semba, K. The In Vivo Selection Method in Breast Cancer Metastasis. Int. J. Mol. Sci. 2021, 22, 1886

https://doi.org/10.3390/ijms22041886

Academic Editor: Yusuke Oshima

Received: 12 January 2021

Accepted: 11 February 2021

Published: 14 February 2021

Publisher's Note: MDPI stays neutral with regard to jurisdictional claims in published maps and institutional affiliations.

Copyright: (c) 2021 by the authors. Licensee MDPI, Basel, Switzerland. This article is an open access article distributed under the terms and conditions of the Creative Commons Attribution (CC BY) license (https:/ / creativecommons.org/licenses/by/ $4.0 /)$.
1 Division of Cellular Signaling, National Cancer Center Research Institute, Tokyo 104-0045, Japan; css124244@akane.waseda.jp (Y.K.); yuyamamo@ncc.go.jp (Y.Y.)

2 Department of Life Science and Medical Bioscience, School of Advanced Science and Engineering, Waseda University, Tokyo 162-8480, Japan; y.han2@kurenai.waseda.jp (Y.H.); a-kazushi@ruri.waseda.jp (K.A.); ksemba@waseda.jp (K.S.)

3 Department of Cell Factory, Translational Research Center, Fukushima Medical University, Fukushima 960-1295, Japan

* Correspondence: jnakayama.re@gmail.com; Tel.: +81-3-3542-2511 (ext. 3664); Fax: +81-3-3543-9305

\begin{abstract}
Metastasis is a complex event in cancer progression and causes most deaths from cancer. Repeated transplantation of metastatic cancer cells derived from transplanted murine organs can be used to select the population of highly metastatic cancer cells; this method is called as in vivo selection. The in vivo selection method and highly metastatic cancer cell lines have contributed to reveal the molecular mechanisms of cancer metastasis. Here, we present an overview of the methodology for the in vivo selection method. Recent comparative analysis of the transplantation methods for metastasis have revealed the divergence of metastasis gene signatures. Even cancer cells that metastasize to the same organ show various metastatic cascades and gene expression patterns by changing the transplantation method for the in vivo selection. These findings suggest that the selection of metastasis models for the study of metastasis gene signatures has the potential to influence research results. The study of novel gene signatures that are identified from novel highly metastatic cell lines and patient-derived xenografts (PDXs) will be helpful for understanding the novel mechanisms of metastasis.
\end{abstract}

Keywords: metastasis; in vivo selection; highly metastatic cancer cell line; breast cancer; xenograft model

\section{Introduction}

Metastasis is a complex event in cancer progression and causes most deaths from cancer. The spreading cancer cells travel from the original primary tumor site to distant organs as a secondary tumor [1]. Stephan Paget proposed the 'seed and soil' hypothesis which is important for understanding multiple steps of metastasis [2,3]. The multistep metastatic cascade consists of (1) progressive growth and invasion into local tissue; (2) vascularization/angiogenesis/lymphangiogenesis; (3) premetastatic niche formation; (4) intravasation; (5) survival in the circulation; (6) extravasation; (7) metastatic niche formation; (8) micrometastasis; and (9) metastatic colonization. To clarify the molecular mechanisms of metastasis, it is necessary to discover genetic profiles and examine gene expression (mRNA, miRNA, and lncRNA), proteomics, metabolomics, and cellular events (signal transduction, cell-cell interactions) at each process of metastatic cascades [4-6].

In the methodological history of metastasis research, Makoto Takahashi developed the first murine model for metastasis, in which cancer cells were injected into the tail vein of mice as a lung metastasis model [7]. The injection of cancer cells into metastatic target organs mimics metastatic events and the microenvironment in the mouse body. Isaiah J. Fidler developed the mouse melanoma cell lines, B16 and its B16-F10 (which have a high metastatic activity to the lung), using tail vein injection into an allograft model and tissue culture techniques [8]. Repeated injection of metastatic cancer cells derived from transplanted murine organs selects the population of highly metastatic cancer cells; 
this method is called in vivo selection. The in vivo selection method and established highly metastatic cancer cell lines have contributed to our understanding of the molecular mechanisms of cancer metastasis.

The establishment of immunodeficient mice such as nude, SCID, NOD, NOD-SCID, NOG, and NSG mice contributed to xenograft studies for metastasis using human cancer cell lines. I. D. J. Bross et al. showed that metastatic spreading occurred in immunodeficient mice by using xenografts of human myeloma and leukemia [9]. Although the greatest problem associated with xenografts is immune rejection, the loss of innate immunity and adaptive immunity in mice by genetic manipulation has enabled the transplantation of cells derived from other species, such as humans [10]. Chloe C. Milsom et al. showed that severely immunodeficient mice were prone to metastases [11]. It has become easier to carry out metastatic studies in graft models. However, problems associated with the graft model include the loss of metastatic interactions with the immune system and the uniqueness of the grafted tumor tissue. Patient-derived xenografts (PDXs) were expanded with the development of immunodeficient mice despite the poor engraft rate, and this model better maintains the uniqueness of the grafted tumor tissue than a xenograft model using a cancer cell line [12,13].

Genetically engineered mouse models (GEMMs) mimic spontaneous metastasis formation from primary tumor $[14,15]$. In addition, the CRISPR/Cas9 system boosted metastasis research using a GEMM [16]. However, previous research has reported that it is difficult to mimic the clinical metastatic pattern and the clinical site of relapse using a GEMM [12]. On the other hand, graft models can mimic various metastatic patterns and steps of metastasis cascade using an appropriate injection method. Highly metastatic cell lines and graft models are enabled to reveal the mechanism of metastasis. Graft models and highly metastatic cancer cell lines are still commonly used in current studies, and their contribution to metastasis research is significant [17-21]. Here, we present an overview of metastasis biology using highly metastatic cell lines established by the in vivo selection method. This review focuses on the characteristics of highly metastatic breast cancer cell lines with the viewing of methodology for establishment.

\section{Differences in Transplantation Methods for the In Vivo Selection}

\subsection{Differences in Highly Metastatic Breast Cancer Cell Lines}

In this section, we discuss that the methodological differences in breast cancer metastasis are important information to select relevant metastasis model. A spontaneous breast cancer metastasis model was generated through orthotopic transplantation into mammary fat pads. This orthotopic model has helped to reveal molecular mechanisms of cancer metastasis and progression [22-24]. Andy J Minn et al. showed that the knockdown of interleukin 13 receptor subunit alpha2 (IL13RA2), secreted protein acidic and cysteinerich (SPARC) and vascular cell adhesion molecule 1 (VCAM1) in MDA-MB-231-LM2 cells (derived from MDA-MB-231-4175 cells) decreased lung metastatic ability after intravenous injection, but these effects did not involve orthotopic tumor growth. On the other hand, knockdown of inhibitor of DNA binding 1 (ID1) caused a significant reduction in both [25]. Their findings suggest that there are two types of metastasis-promoting genes; one promotes cancer progression in only a metastatic site, and the other leads to progression in both orthotopic and metastatic sites.

Recent studies have reported a relationship between the transplantation method for in vivo selection and metastasis gene signatures. Jun Nakayama et al. showed the differences between orthotopic transplantation and intravenous injection via the establishment of a lung metastatic breast cancer cell line. They established lung metastatic MDA-MB-231 cells by two methods-orthotopic transplantation and intravenous injection. The gene signatures for the established metastatic cells were remarkably different. Their model showed that chemotaxis and cell adhesion genes were enriched in the orthotopic lung metastasis model [26]. In addition, Nir Pillar et al. showed that microRNA expression profiles are different between orthotopic transplantation and intravenous injection [27]. 
Christina Ross et al. performed a comparative analysis of orthotopic transplantation and intravenous injection, allograft models, and GEMMs. Interestingly, their study confirmed not only the divergence in gene signatures between routes of the transplantation model, but also that the extent of this variation is unique to each cell line. Gene signatures in the orthotopic transplantation are enriched in T-cell activation and immune-related pathways. In addition, allograft models showed more mesenchymal-like expression than GEMMs [28].

These studies suggest that the selection of breast cancer metastasis models for the study of metastasis gene signatures has the potential to influence research results. Many gene signatures in orthotopic breast cancer metastasis have not yet been studied, and we believe that these studies will contribute to the elucidation of novel mechanisms of breast cancer metastasis and the development of a cure for breast cancer metastases. Although recent studies show a novel potential of cancer cell line studies [29], generally most findings from cancer cell line models are difficult to translate into clinical practice [30]. Cancer cell lines have the limitation in preclinical research, since cancer cell lines have acquired the genetic mutations which enable them to proliferate in a plastic dish [31,32]. On the other hand, PDX models have shown to be clinically relevant in comparison to breast cancer cell lines [33].

\subsection{Breast Cancer Metastasis in PDX Models}

PDX models are superior to cancer cell line xenograft models and GEMMs, since PDX models reflect the diversity and heterogeneity of human tumors [34,35]. In breast cancer research, PDX models of each breast cancer subtype are developed for preclinical studies [33]. Recent studies reported that 3887-LM, which is a highly lung metastatic basal-like breast cancer PDX model, is developed by serial transplantation as an in vivo selection method [36] (Table 1). Adrián González-González et al. reported that SMAD2/3/4 and mTORC2 signaling mediate lung metastasis in a 3887-LM PDX model [37]. Marta PaezRibes et al. established HCI-002 LM2-1 (highly lung metastatic) triple-negative breast cancer (TNBC) PDXs model by serial orthotopic transplantation [38]. Masanori Oshi et al. established novel brain metastasis models in TNBC PDX by orthotopic transplantation and intracranial injection method [39]. Interestingly, Diane Lefley et al. showed the novel bone metastasis model using a PDX model with bone tissue derived from humans [40]. Their metastasis model can mimic a human bone microenvironment in immunodeficient mice, and cancer cells can metastasize to human metastatic organs. Since PDX models of tumor cells and metastatic organs have established, it may be possible to observe human cancer metastasis in mice.

Table 1. List of highly metastatic PDX models in breast cancer.

\begin{tabular}{ccccc}
\hline PDX Models & Subtype & Method & Metastatic Organs & Reference \\
\hline 3887-LM & Basal-like (TNBC) & Orthotopic & Lung & {$[36]$} \\
HCI-002 LM2-1 & TNBC & Orthotopic & Lung & {$[38]$} \\
Brain PDX (B0 B3) & TNBC & Intracranially & Brain & {$[39]$} \\
MFP PDX (M0 M3) & TNBC & Orthotopic & Brain & {$[39]$} \\
\hline
\end{tabular}

However, PDX models also have technical problems of the establishment process. Major problems are the high cost for maintenance and a low ratio of engraftment of tumor tissues derived from patient. Additionally, the engraftment sites of the xenograft also affect the success rate of establishment of PDXs [41]. Since the transplantation methods have effects on the metastasis gene signatures and the characters of cancer cell, study is needed for elucidating the differences in the PDX character by each engraftment site.

\section{Highly Metastatic Breast Cancer Cell Lines}

\subsection{Introduction of Highly Metastatic Breast Cancer Cell Lines}

In a clinical study, microarray analysis revealed the heterogeneity and diversity of gene expression in breast cancer patients, and gene signatures were correlated with a poor 
prognosis [42-44]. On the other hand, in an experimental metastasis study, Yibin Kang et al. performed an expression analysis of highly metastatic human breast cancer cell lines established by in vivo selection and revealed a metastatic molecular signature [45]. In addition, Andy J Minn et al. found that gene signatures from highly metastatic human cell lines were correlated with poor progression in breast cancer patients [25]. Breast cancer metastasizes to distant multiorgan sites, such as the lung, bone, brain, and liver, via hematogenous or lymphatic metastases. An analysis of highly metastatic cancer cell lines that have metastatic organ tropism has also demonstrated metastasis-promoting genes that contribute to organ tropism $[1,46,47]$. Since this discovery, many metastasis-promoting genes, suppressor genes and molecular mechanisms of metastasis have been identified from the analysis of gene signatures of highly metastatic cell lines $[48,49]$. Although the highly metastatic cell lines that are frequently used are limited, many metastatic cell lines have been established by various transplantation methods (Figure 1 and Table 2) [50-57]. In addition, to promote the exchange of information on these valuable resources, the brain metastasis cell lines panel (BrMPanel) [58] and the metastasis map (MetMap) of human cancer cell lines [59] has been published as a useful public dataset. Cataloging the metastatic tropism and activity of cancer cell lines has reached a major turning point by these datasets [58-60]. Here, we describe a study of metastasis biology with gene expression profiling using highly metastatic breast cancer cell lines established by in vivo selection.

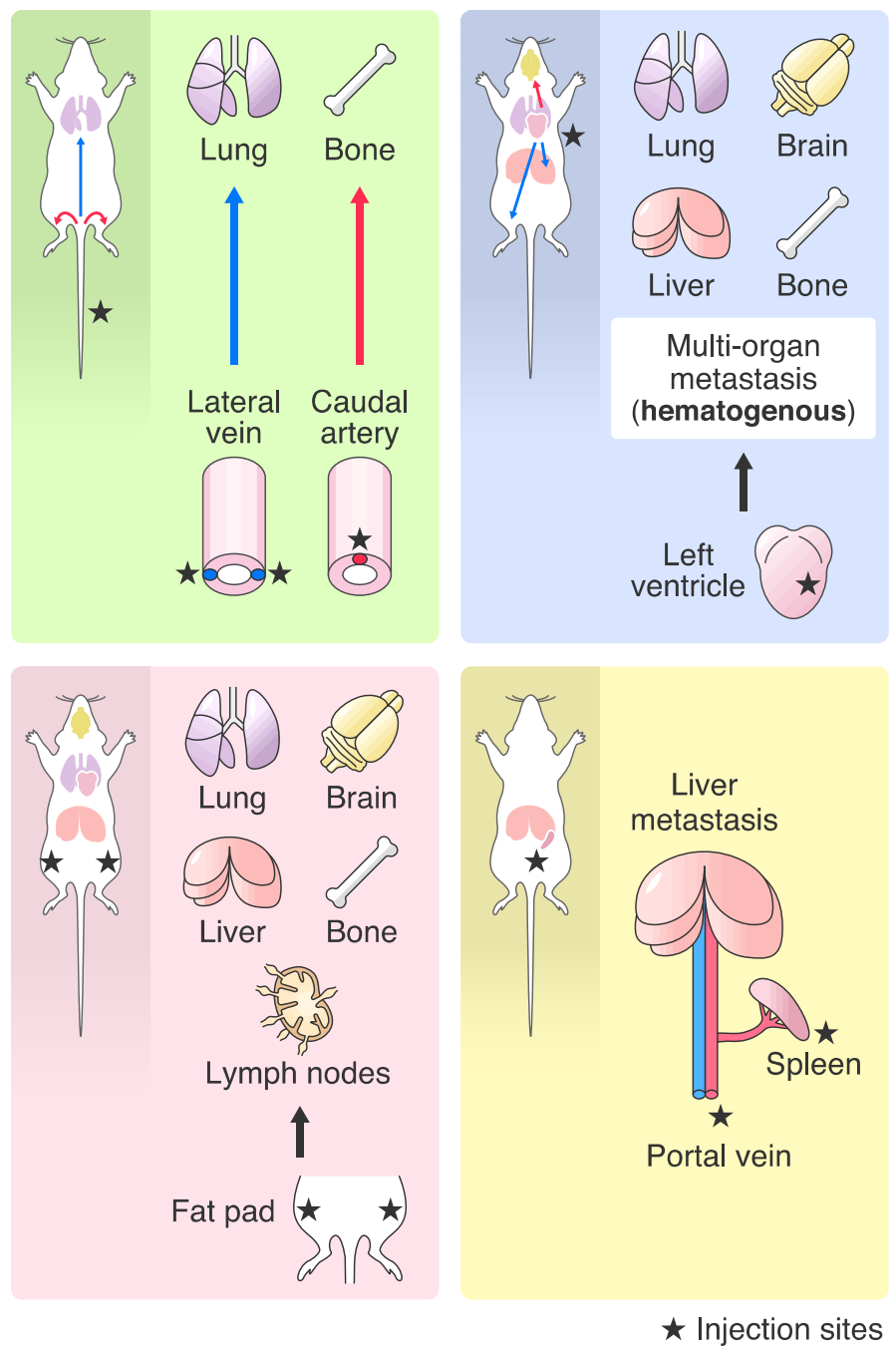

Figure 1. Transplantation methods in tropic organs. Tail vein injection (upper left), intracaudal artery injection (upper left), intracarotid injection and intracardiac injection (upper right) are categorized as 
intravascular transplantation. These methods can deliver cancer cells to distant organs via the blood circulation and can be used to generate a hematogenous metastasis model (study of micrometastasis formation and metastatic colonization in distant organs, extravasation process and metastatic niche formation). The orthotopic transplantation method can mimic tumor progression from the primary tumor to distant organs and be used as a hematogenous or lymphogenous metastasis model (lower left) (study of micrometastasis formation and metastatic colonization in distant organs, extravasation process, metastatic niche formation, survival in the circulation, intravasation, preparation of the pre-metastatic niche, vascularization/angiogenesis/lymphangiogenesis and progressive growth and invasion into local tissue). The spleen transplantation method can be used to generate a liver metastasis model via hematogenous metastasis (lower right) (study of micrometastasis formation and metastatic colonization in distant organs, extravasation process, metastatic niche formation, survival in the circulation, intravasation).

Table 2. List of highly metastatic breast cancer cell lines.

\begin{tabular}{|c|c|c|c|c|c|}
\hline Cell Line & Species of Origin & Subtype & Method & Metastatic Organ & References \\
\hline 4T1-2776, 2792, 2869 & Mouse & Basal-like (TNBC) & Spleen transplantation & Liver & [61] \\
\hline $4 \mathrm{~T} 1.3$ & Mouse & Basal-like (TNBC) & Orthotopic & Bone & [62] \\
\hline 4T1E/M3 & Mouse & Basal-like (TNBC) & Intravenous & Bone & [63] \\
\hline 4T1LM & Mouse & Basal-like (TNBC) & Orthotopic & Liver & {$[64]$} \\
\hline C3L5 & Mouse & Unknown & Subcutaneous & Lung & {$[65]$} \\
\hline CN34-LM1 & Human & Claudin-low (TNBC) & Intravenous & Lung & {$[66]$} \\
\hline MCF7-BM02 & Human & Luminal A & Intracaudal arterial & Bone & {$[67]$} \\
\hline MDA-MB-231-BM (BoM: 1833) & Human & Claudin-low (TNBC) & Intracardiac & Bone & {$[45]$} \\
\hline MDA-MB-231-HM & Human & Claudin-low (TNBC) & Intravenous & Lung & {$[68]$} \\
\hline MDA-MB-231-HM.LNm5 & Human & Claudin-low (TNBC) & Orthotopic & Lymph node & {$[69]$} \\
\hline MDA-MB-231-LM05 & Human & Claudin-low (TNBC) & Orthotopic & Lung & {$[26]$} \\
\hline MDA-MB-231-LM1-2-1 & Human & Claudin-low (TNBC) & Intravenous & Lung & {$[26]$} \\
\hline MDA-MB-231-LM2 (4175) & Human & Claudin-low (TNBC) & Intracardiac/Intravenous & Lung & {$[25]$} \\
\hline MDA-MB-231-luc-D3H2LN & Human & Claudin-low (TNBC) & Orthotopic & $\begin{array}{l}\text { Lymph node } \\
\text { Lung, Liver }\end{array}$ & [50] \\
\hline MDA-MB-231HMLNm5 & Human & Claudin-low (TNBC) & Orthotopic & $\begin{array}{l}\text { Lymph node, Spleen and } \\
\text { Paraspinal tissue }\end{array}$ & [69-71] \\
\hline MDA-MB-468LN & Human & Basal-like (TNBC) & Orthotopic & Lymph node & [72] \\
\hline mtMDA & Human & Claudin-low (TNBC) & Intracardiac & Bone & [73] \\
\hline SUM159-M1a & Human & Claudin-low (TNBC) & Intravenous & Lung & [74] \\
\hline
\end{tabular}

Please see the Brain Metastasis Cell Lines Panel for highly metastatic brain cell (https://apps.cnio.es/app/BrainMetastasis/CellLines accessed on 11 January 2021) [58].

\subsection{Lung Metastasis}

The intravenous injection (tail vein injection) method is frequently used to generate lung metastasis models [7]. Since the primary tumor forms long after orthotopic transplantation into mammary fat pads, the intravenous model is convenient for the study of lung metastasis. Andy J. Minn et al. established MDA-MB-231-LM2 cells (lung metastatic cells) [25], as well as CN34-LM1 [66] and MDA-MB-231-HM cells [68] by intravenous transplantation. These three cell lines are the most frequently examined cell lines in breast cancer lung metastasis studies. However, there are other highly lung metastatic cell lines, such as MDA-MB-231-LM1-2-1 (tail vein transplant), and MDA-MB-231-LM05 (orthotopic transplant) [26]. Moreover, the C3L5 cell line (subcutaneous transplant) is a highly lung metastatic cell line derived from a spontaneous mammary tumors [65].

In previous studies using MDA-MB-231-LM2 cells, epiregulin (EREG), C-X-C motif chemokine ligand 1 (CXCL1), matrix metalloproteinase 1 (MMP1), MMP2, SPARC, VCAM1, and cyclooxygenase 2 (COX2) were elucidated as genes that mediate lung metastasis [25]. Furthermore, the expression changes in genes related to metastasis initiation (cathepsin $\mathrm{C}$ : $C T S C$, endoglin: $E N G$, bone morphogenetic protein 2: BMP2) and metastasis suppression (cystatin 1: CST1, CST2, sodium channel non-voltage-gated 1: SCNN1A, BMP4) have also been confirmed [75]. Tenascin C (TNC), acetylgalactosaminyltransferase 14 (GALNT14) and $C D 70$ are known as genes related to lung-specific metastasis. TNC promotes $\mathrm{NOTCH}$ and WNT signaling and cancer cell survival in the early stage of lung metastasis and then promotes lung-specific metastasis [76]. The expression of GALNT14 is induced by the KRAS-PI3K pathway, and increasing of SRY-box 4 (SOX4) expression by O-GalNAcylation of the BMP receptor. It has been reported that the self-renewal ability of MDA-MB-231-LM2 
and CN34-LM1 cells is enhanced by inhibiting the suppressive effect of lung-derived BMPs and, therefore, promotes cell division [77]. In addition, MDA-MB-231-LM2 and CN34-LM2 cells highly express CD70, which is also highly expressed in clinical samples with lung metastases. Although the detailed function of CD70 in lung metastasis has not yet been reported, CD70 is one of lung metastasis gene signatures [78]. Moreover, multiple genes are sometimes required to promote lung metastasis, rather than independent genes.

Furthermore, decreases in miR-335, miR-206, and miR-126 expression [66] and increases in circIRAK3 expression [79] were observed as changes in non-coding RNA expression levels. miR-335 regulates the expression of several genes such as TNC and SOX4, as described above [66]. However, most of the metastasis-related genes and miRNAs that have been discovered are derived from TNBC. There is still a lack of studies on other subtypes of breast cancer.

\subsection{Bone Metastasis}

Bone metastasis is not lethal; however, it remains incurable by any available clinical treatments and causes a series of skeletal-related events [80], induces severe pain in patients, and directly affects quality of life (QOL) [81]. One concept is that breast cancer cells invading the bone are usually accompanied by interactions with osteoblasts and osteoclasts [82]. Breast cancer cells respond to parathyroid hormone-associated protein (PTHrP), converting transforming growth factor beta (TGF- $\beta$ ), cytokines, chemokines, and other growth factors in the bone microenvironment, and mediate the tumor invasion and colonization. Several in vivo injection methods, including orthotropic transplantation, tail vein injection, intracardiac injection, and hind limb injection, can be used to study bone metastasis. Orthotropic models are usually used to study spontaneous metastasis [83], in which metastases have more difficulty forming in the bone than in soft tissue. As the tail vein injection results in a similar phenotype, it is more often used to study lung metastasis than bone metastasis. Intracardiac injection into the left ventricle is the most common technique employed to study organ-tropic metastasis and to establish bone metastatic cell lines [84]. A recent study reported the application of intracaudal arterial injection to establish bone metastatic cell lines [51]. After all, bone metastasis models are more difficult to generate than lung and liver models.

Yibin Kang et al. first applied MDA-MB-231 cells to establish bone metastasis sublines by intracardiac injection. Interleukin 11 (IL11) and connective tissue growth factor (CTGF) activate osteolytic factors, and their expression is further increased by TGF- $\beta$ in MDA-MB231 bone metastasis cells (MDA-MB-231-BM cells; intracardiac injection) [45]. Increased C-X-C motif receptor 4 (CXCR4) expression is present in breast cancer cells that have metastasized to the bone through hypoxia inducible factor 1 alpha subunit $(H I F 1 A)$ and TGF- $\beta$ signaling [85]. A model in which MDA-MB-231 cells were injected into the hind limb musculature proved that MMP1 released by metastatic cells activates osteoclast precursor cells and improves osteoclast resorption [86]. MDA-MB-231-BM cells release dickkopf 1 (DKK1) to increase the serum level and seed bone metastasis through Wnt signaling [87]. E-selectin promotes the mesenchymal-to-epithelial transition process and bone-specific metastasis [74]. Bone metastatic MDA-MB-231 cells (mtMDA) established by intracardiac injection promoted the secretion of S100 calcium binding protein A4 (S100A4), which participates directly in the formation of osteolytic lesions of bone metastases [73].

Moreover, the highly metastatic 4T1E/M3 murine breast cancer cell line (intravenous injection) established by intracardiac injection showed upregulated intracellular adhesion molecule 1 (ICAM1) and its function in tumor colonization [63]. The 4T1.3 cell lines (highly bone metastatic subline) were established by orthotopic transplantation, which expresses C-C motif ligand 4 (CCL4) for interaction with fibroblasts expressing C-C motif receptor 5 (CCR5) in the bone microenvironment [62]. Most of bone metastatic cell lines also are established from TNBC. Yuxuan Han et al. established luminal bone metastatic cell lines (MCF7-BM02) by intracaudal arterial injection [67]. These cell lines will be a reasonable model for bone metastasis in luminal breast cancer. 


\subsection{Brain Metastasis}

Breast cancer has the second highest incidence of brain metastasis following lung cancer [88]. Patients with brain metastasis have several neurological symptoms, such as headache, cognitive impairment, and convulsion, which worsen the patient's QOL [89]. However, only a few strategies can be used to specifically treat brain metastasis, and in most cases, therapy for brain metastasis is palliative care [90]. To elucidate the mechanism of brain metastasis for the development of effective treatments, highly metastatic brain cell lines have been established, and their gene expression profile has been determined. Graft models of brain metastasis are generated mainly by four methods-intracardiac injection, intracarotid injection, intracranial injection, and intravenous injection [53,91-94]. However, most highly brain metastatic cell lines have been established by the intracardiac injection method.

Most studies on brain metastasis in breast cancer have been conducted using the brain metastatic derivatives of TNBC cell lines. The highly brain metastatic cell lines MDA-MB-231-BrM2 and CN34-BrM2 cells were established via the intracardiac injection method [91]. Gene expression analysis of these cells revealed that $C O X 2$, heparin binding EGF like growth factor (HBEGF), and ST6 N-acetylgalactosaminide alpha-2,6-sialyltransferase 5 (ST6GALNAC5) were involved in brain metastasis of breast cancer by mediating cancer cell passage through the blood-brain barrier (BBB) [91]. Cathepsin S (CTSS), some types of serpins (inhibitors of plasminogen activators), cell adhesion molecule L1 (L1CAM), glutamate receptor ionotropic N-methyl D-asparate 2B (GRIN2B), protocadherin 7 (PCDH7) and connexin 43 (CX43) were also reported to promote breast to brain metastasis, as revealed by the expression analysis of brain metastatic cells derived from MDA-MB-231 cells [18,95-98]. In addition, highly brain metastatic MDA-MB-231-BMD2a and BMD2b cell lines, were established by repetitive intracardiac injection of MDA-MB-231-luc-D3H2LN cells [99].

TNBCs, as well as HER2-positive breast cancers, are prone to metastasize to the brain [100]. The MDA-MB-231-BR-HER2 and MCF7-HER2-BR3 cell lines are used as a model of brain metastasis [19,101-104]. Additionally, the BT474.Br cells (derived from BT474-m1, intracarotid transplantation) [105-107], SKBRM cells [108,109], JIMT-1-BR3, SUM-190-BR3 cells (intracardiac injection) [110-112], MDA-MB-361-BR2/BR3 cells (intracardiac injection) [113] and HCC1954-BrM1 cells [93] are often used for the study of brain metastasis in HER2-positive breast cancer.

Regarding murine TNBC cell lines, the brain-metastatic variants of $4 \mathrm{~T} 1$ cells are often used. The 4TBM cells (the brain-metastatic derivative of heart-metastasized 4T1 cells) were established by the orthotopic injection method [114]. For the murine HER2positive breast cancer cell line, the brain metastatic cells expressing avian erythroblastosis oncogene B2 (ErbB2) (ErbB2-BrM2) were established from MMTV-driven NeuNT transgenic murine mammary tumor cells by repetitive in vivo selection using the intracardiac injection method $[93,96,115]$. Various brain tropic breast cancer cell lines have been established. Several genes associated with brain metastasis have been identified by gene expression profiling of those cell lines.

\subsection{Liver Metastasis}

Liver metastases are observed in approximately $50 \%$ of metastatic breast cancer patients [116]. Patients with breast-to-liver metastasis have unfavorable prognoses and efficacious treatments for liver metastasis are required $[117,118]$. For liver metastasis in breast cancer, few highly metastatic cell lines have been established so far. MDA-MB231HMLNm 5 cells are highly metastatic cells with a metastatic potential not only to the liver but also to the lung, axillary lymph nodes, spleen, and paraspinal tissue [69-71,75,119,120]. 
Murine mammary liver metastatic cell lines are often used. In many cases, 4T1-derived liver metastatic cells have been used to study liver metastasis in breast cancer. Liver metastatic $4 \mathrm{~T} 1$ (2776, 2792, and 2869 subclones) cell lines were established by spleen transplantation as the in vivo selection method [61]. Comparative analysis of gene expression profiles between lower liver metastatic cells and highly liver metastatic cells revealed that claudin 2 (CLDN2) was upregulated in the aggressive populations and that it promoted liver metastasis by increasing cancer cell adhesion to extracellular matrix components via integrin complexes [61]. In addition, Nuray Erin et al. established liver metastatic 4T1 cells (4TLM cells) from heart-metastasized 4T1 cells (4THM cells) by orthotopic transplantation and compared the gene expression profile of 4TLM cells with that of their parental cells (4T1 cells) [64]. In 4TLM cells, the gene signatures involved in cell adhesion and cell junctions were downregulated [64]. The CD34 gene is highly expressed in 4TLM primary tumors, reflecting their metastatic potential [114]. Highly liver metastatic 4T1 cell lines have contributed to the research on hepatic metastasis in breast cancer. However, regarding human cell lines, only a few metastatic cell lines have been established in the field of hepatic metastasis. The establishment of the novel liver metastatic human breast cancer cell lines will be helpful for developing an effective treatment for hepatic metastasis.

\subsection{Lymph Node Metastasis}

Metastasis to the sentinel lymph node often occurs in breast cancer. The lymphatic pathways in the human breast include the axilla, internal breast, and supraclavicular lymph node, and are related to distant organ metastasis. Since lymph nodes can also access the blood circulation via lymphatic vessels, metastasis to lymph nodes has the potential to induce subsequent systemic metastasis [72,121]. Many types of studies on lymph node metastasis of breast cancer are based on clinical specimens.

Most of highly lymph node metastatic breast cancer cell lines have been established by orthotopic transplantation. This is because the intravascular injection method cannot imitate the processes of lymphogenous metastasis in mice. MDA-MB-468LN [72], MDA-MB-231luc-D3H2LN [50], MDA-MB-231H-RFP [122], and MDA-MB-231-HM.LNm5 [69] cell lines were established as lymph node metastatic cell lines from the TNBC cell lines. All these cell lines metastasize to axillary lymph nodes after orthotopic transplantation. Gene expression analysis showed that the mRNA levels of metallothionein 1A (MT1A), MT1E, MT1M, and MT2A are high and that those of collagen type VI alpha 1 (COL6A1), COL6A2, and COL18A1 are suppressed in MDA-MB-231-HMLNm5 cells [75].

\section{Differences in Metastasis Gene Signatures According to the Molecular Subtypes of Breast Cancer}

The intrinsic subtypes of breast cancer are classified based on the gene expression profiles of hormone receptors (HRs) (estrogen receptor, ER; progesterone receptor, PR) and human epidermal growth factor receptor 2 (HER2). There are four subtypes-luminal A, luminal B, HER2/ERBB2-overexpressing, and TNBC [123]. Subtype classification is very important in determining the treatment strategy for breast cancer.

The site of metastasis tends to differ depending on each subtype's metastatic tropism (Figure 2) [124]. Breast cancer patients of the luminal type (HR+/HER - ) show more than twice as much bone metastasis than those of the other subtypes [125,126]. In contrast, TNBC tumors have a high overall rate of brain, liver, and lung metastases [118,126-129]. Each subtype of breast cancer exhibits different metastatic behaviors to the sites of distant metastasis [129]. Unique gene signatures may be involved in the organ-specific metastasis according to the breast cancer subtype [130]. 


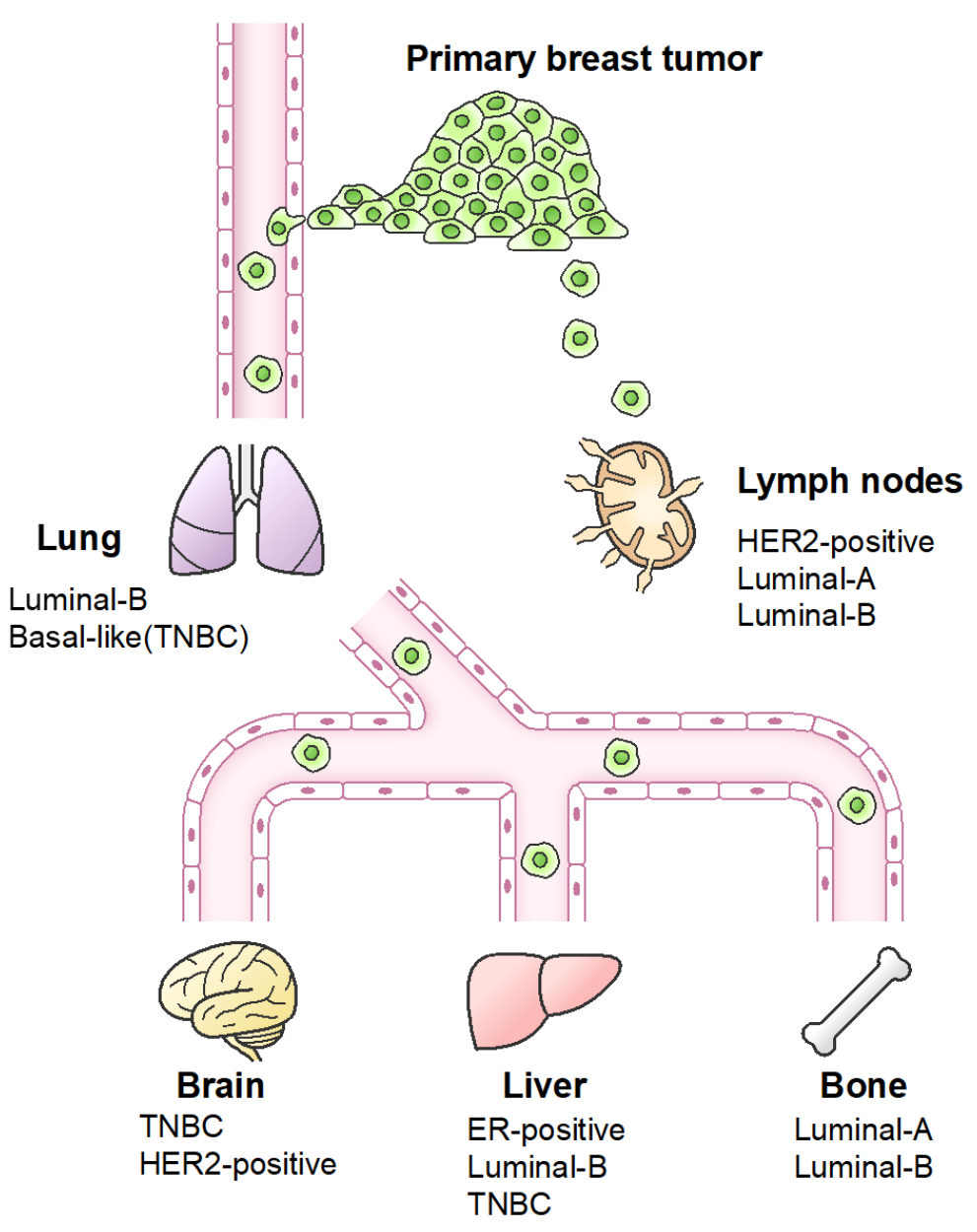

Figure 2. Breast cancer subtypes and tropism of distant metastases. The breast cancer subtypes are classified based on estrogen receptor (ER), human epidermal growth factor receptor 2 (HER2), and progesterone receptor (PR). There are differences of metastatic organ tropism between breast cancer subtypes.

Therefore, metastasis gene signatures identified from TNBC may not be able to regulate the metastatic process of other subtypes. This raises the crucial problem of treating metastasis, in that the molecular mechanism of metastasis differs not only by the organ site but also by the cancer subtype. For example, the metastatic gene COX2 is undetectable in MCF7 cells but is overexpressed in MDA-MB-231 cells [131]. Runt-related transcription factor 2 (RUNX2) knockdown in MDA-MB-231 cells downregulates the expression of the bone-related genes to induce bone metastasis. However, RUNX2 knockdown in MCF7 cells cannot alter the expression of bone-related genes [132]. Additionally, the gene expression profile is different between MCF7-BM (derived from bone metastasis) and MDA-MB-231$\mathrm{BM}$ cells established by intracaudal arterial injection, suggesting that the luminal breast cancer may have novel molecular mechanisms as compared to TNBC [67].

Due to a lack of HR+ models, little is known about the role of hormones in breast cancer metastasis or the hormone response to the organ-specific microenvironment [133]. However, increasing evidence has shown that the breast cancer subtype enables the prediction of an increased risk of site-specific metastasis. The study of metastasis in each subtype can provide a more comprehensive understanding and reference for clinical treatment $[128,134]$. The elucidation of molecular subtype-dependent mechanisms of metastasis is a major issue in future research, and it is necessary to construct a novel metastasis model for other subtypes. 


\section{Genomic Profiling of Breast Cancer}

The analysis of genetic information from clinical samples has demonstrated the various metastatic patterns of breast cancer. Gene signatures that orchestrate the metastatic phenotype have been characterized. In 2000, Charlses M Perou et al. applied complementary DNA microarrays and reported 8102 human genes associated with estrogen receptor-negative and estrogen receptor-positive breast cancer according to their genetic patterns [135]. In 2002, Marc J van de Vijver et al. used an oligonucleotide microarray to characterize 295 young patients with or without breast cancer lymph node metastasis. The data revealed several gene signatures such as minichromosome maintenance complex component 6 (MCM6), MMP9, and cyclin E2 (CCNE2) that were associated with the risk of metastasis [44]. Transcriptome profiles also showed metastatic gene signatures associated with a poor prognosis in breast cancer patients. Based on the vast amount of work and the development of next generation sequencing, the cancer genome atlas (TCGA) sequenced and analyzed over 25 types of more than 10,000 primary tumors to characterize the DNA, RNA, and protein levels [136]. Moreover, the molecular taxonomy of breast cancer international consortium (METABRIC) cohort profiled the copy number, gene expression and proteome of 2000 primary tumors, and revealed the impact of copy number aberrations in breast cancer [137-139]. The primary tumor databases were frequently applied to the comparison with metastasis analysis. For example, Lucy R Yates et al. showed that the metastatic or disseminated tumor cells from breast cancer primary tumors acquired further mutation inactivation on switching defective (SWI)/sucrose nonfermenting (SNF) and JAK2-STAT3 pathways [140]. Moreover, Runpu Chen et al. applied static sample data from TCGA and METABRIC to study breast cancer progression. The mathematic model was able to demonstrate that the breast cancer subtypes can shift during metastasis [141].

However, it requires high bioinformatic technique to analyze the metastatic data from the primary tumor database. A more comprehensive analysis of metastatic cancers was performed by Dan R. Robinson et al. in 2017. They sequenced the genomic DNA and RNA of 500 metastatic specimens and released the MET500 dataset [142]. The MET500 dataset showed extensive genomic profiles of metastasis in clinical patients, and an epithelial-tomesenchymal transition (EMT)-like inflammation signature and proliferation signature were observed in metastatic tissues.

Meanwhile, Yibin Kang et al. obtained the transcriptomic profile of MDA-MB-231 bone metastatic cells selected in vivo in 2003, and the osteolytic bone metastatic genes as mentioned in Section 3 were extracted [45], where they found that the genes of bone metastasis signatures were unidentified in previous breast cancer signatures of poor prognosis. This result raised the attention on the emergency of the profile of organ-tropic metastasis. Therefore, the lung metastatic in vivo selection was profiled by MDA-MB231 and 1894 cells [25], as well as the brain metastasis in vivo selection by CN34 and MDA-MB-231 [91]. The organ-specific metastasis gene signatures were extracted based on these profiles. Brain and lung metastatic genes COX2, EREG, bone metastatic genes CXCR4, MMP1, etc., were identified and characterized. Yuxuan Han et al. established luminal-type bone metastatic cell line by MCF7 cells [67] and profiled luminal type breast cancer metastatic signatures such as trefoil factor 1 (TFF1), interferon alpha inducible protein 6 (IFI6) and galectin 1 (LGALS1), which were confirmed as metastasis-positive signatures [143] (Table 3). The high-throughput technologies have developed rapidly, and scientists are able to understand both the genomic and transcriptomic changes during cancer metastasis in clinical samples and experimental models.

The analysis of genetic information from clinical samples has demonstrated the various metastasis gene signature in breast cancer. Metastasis gene signatures that orchestrate the metastatic phenotype are characterized. From the establishment of novel highly metastatic cell lines and the identification of novel metastasis gene signatures, extensive clinical analysis with genomics and transcriptomics will be needed to identify their clinical significance. Most of the cohort studies have analyzed primary lesions, but it will be necessary to analyze the profile of metastatic lesions. 
Table 3. Gene signatures of in vivo selection.

\begin{tabular}{ccc}
\hline Metastasis Organ & Gene Signatures & Reference \\
\hline Lung & EREG, CXCL1, MMP1, MMP2, & {$[25]$} \\
Lung & SPARC, VCAM1, COX2 & {$[66]$} \\
Bone & CD70, SOX4 & {$[45]$} \\
Bone & IL1, CTGF, CXCR4, OPN & {$[87]$} \\
Bone & DKK1 & {$[73]$} \\
Brain & S100A4 & {$[91]$} \\
Brain & COX2, HBEGF, ST6GALNAC5 & {$[18,95-97]$} \\
Liver & CTSS, L1CAM, GRIN2B, PCDH7, CX43 & {$[61]$} \\
\hline
\end{tabular}

\section{Conclusions}

The in vivo selection method in breast cancer research has revealed many molecular mechanisms of metastasis and contributed to our understanding of cancer progression with distant metastasis. In this review, we discussed the characteristics of highly metastatic breast cancer models, including cancer cell lines and PDXs, with the view of methodology for establishment. Recent breast cancer metastasis studies suggest that even cancer cells that metastasize to the same organ show various metastatic cascades and patterns upon changing the transplantation method for in vivo selection. Also, various metastasis gene signatures can be revealed by changing the method and the molecular subtypes of breast cancer. However, most of the cancer cell line models have the limitation of the preclinical study. More establishment and magnification of the highly metastatic PDX models are necessary for preclinical metastasis study. On the other hand, some of the highly metastatic cancer cell line models have been also contributed to clinical research. Researchers will need to select an appropriate metastasis model by focusing not only on the metastatic organs but also on the metastatic cascade, mechanism and transplantation method. The appropriate selection of highly metastatic cancer cell line models and PDX models will be helpful for the elucidation of the breast cancer metastasis and the development of therapeutic strategies for metastasis.

Author Contributions: Conceptualization, J.N.; writing—original draft preparation, J.N.; writingreview and editing, J.N., Y.H., Y.K., K.A., Y.Y. and K.S.; project administration, J.N.; funding acquisition, J.N and Y.H. All authors have read and agreed to the published version of the manuscript.

Funding: This work was supported in part by JSPS KAKENHI (Grant Numbers 18K16269: Grant-in-Aid for Early-Career Scientists to J.N., Grant Number 20J01794 to J.N. and 20J23297 to Y.H.: Grant-in-Aid for JSPS Fellows).

Acknowledgments: We are grateful to Wataru Takayanagi from LAIMAN (www.laiman.co.jp, accessed on 11 January 2021) for making the figures in the present manuscript.

Conflicts of Interest: The authors declare no conflict of interest.

\begin{tabular}{ll}
\multicolumn{2}{l}{ Abbreviations } \\
SCID & Severe combined immunodeficiency \\
NOD & Non-obese diabetic \\
GEMM & Genetically engineered mouse model \\
PDX & Patient derived xenograft \\
MetMap & Metastasis map \\
QOL & Quality of life \\
BBB & Blood-brain barrier \\
HR & Hormone receptor \\
HER2 & Human epidermal growth factor receptor 2 \\
ER & Estrogen receptor \\
PR & Progesterone receptor
\end{tabular}




$\begin{array}{ll}\text { TNBC } & \text { Triple negative breast cancer } \\ \text { EMT } & \text { Epithelial to mesenchymal transition } \\ \text { TCGA } & \text { The cancer genome atlas } \\ \text { METABRIC } & \text { Molecular taxonomy of breast cancer international consortium }\end{array}$

\section{References}

1. Valastyan, S.; Weinberg, R.A. Tumor Metastasis: Molecular Insights and Evolving Paradigms. Cell 2011, 147, 275-292. [CrossRef]

2. Paget, S. Distribution of secondary growths in cancer of the breast. Lancet 1889, 133, 571-573. [CrossRef]

3. Fidler, I.J. The pathogenesis of cancer metastasis: The 'seed and soil' hypothesis revisited. Nat. Rev. Cancer 2003, 3. [CrossRef]

4. Suhail, Y.; Cain, M.P.; Vanaja, K.; Kurywchak, P.A.; Levchenko, A.; Kalluri, R.; Kshitiz. Systems Biology of Cancer Metastasis. Cell Syst. 2019, 9, 109-127. [CrossRef] [PubMed]

5. Obenauf, A.C.; Massague, J. Surviving at a Distance: Organ-Specific Metastasis. Trends Cancer 2015, 1, 76-91. [CrossRef] [PubMed]

6. Talmadge, J.E.; Fidler, I.J. AACR Centennial Series: The Biology of Cancer Metastasis: Historical Perspective. Cancer Res. 2010, 70, 5649-5669. [CrossRef]

7. Takahashi, M. An experimental study of metastasis. J. Pathol. Bacteriol. 1915, 20,1-13. [CrossRef]

8. Fidler, I.J. Selection of Successive Tumour Lines for Metastasis. Nat. New Biol. 1973, 242, 148-149. [CrossRef]

9. Bross, I.D.J.; Viadana, E.; Pickren, J.W. The metastatic spread of myeloma and leukemias in men. Virchows Arch. 1975, 365, 91-101. [CrossRef]

10. Belizario, J.E. Immunodeficient Mouse Models: An Overview. Open Immunol. J. 2009, 2, 79-85. [CrossRef]

11. Milsom, C.C.; Lee, C.R.; Hackl, C.; Man, S.; Kerbel, R.S. Differential post-surgical metastasis and survival in SCID, NOD-SCID and NOD-SCID-IL-2R $\gamma($ null $)$ mice with parental and subline variants of human breast cancer: Implications for host defense mechanisms regulating metastasis. PLoS ONE 2013, 8, e71270. [CrossRef]

12. Bos, P.D.; Nguyen, D.X.; Massagué, J. Modeling metastasis in the mouse. Curr. Opin. Pharmacol. 2010, 10, 571-577. [CrossRef] [PubMed]

13. Gómez-Cuadrado, L.; Tracey, N.; Ma, R.; Qian, B.; Brunton, V.G. Mouse models of metastasis: Progress and prospects. Dis. Model. Mech. 2017, 10, 1061-1074. [CrossRef] [PubMed]

14. Kersten, K.; de Visser, K.E.; van Miltenburg, M.H.; Jonkers, J. Genetically engineered mouse models in oncology research and cancer medicine. EMBO Mol. Med. 2017, 9, 137-153. [CrossRef] [PubMed]

15. Fantozzi, A.; Christofori, G. Mouse models of breast cancer metastasis. Breast Cancer Res. 2006, 8, 212. [CrossRef]

16. Tian, X.; Gu, T.; Patel, S.; Bode, A.M.; Lee, M.-H.; Dong, Z. CRISPR/Cas9-An evolving biological tool kit for cancer biology and oncology. NPJ Precis. Oncol. 2019, 3, 8. [CrossRef] [PubMed]

17. Boire, A.; Zou, Y.; Shieh, J.; Macalinao, D.G.; Pentsova, E.; Massagué, J. Complement Component 3 Adapts the Cerebrospinal Fluid for Leptomeningeal Metastasis. Cell 2017, 168, 1101-1113. [CrossRef] [PubMed]

18. Er, E.E.; Valiente, M.; Ganesh, K.; Zou, Y.; Agrawal, S.; Hu, J.; Griscom, B.; Rosenblum, M.; Boire, A.; Brogi, E.; et al. Pericyte-like spreading by disseminated cancer cells activates YAP and MRTF for metastatic colonization. Nat. Cell Biol. 2018, 20, 966-978. [CrossRef]

19. Rodrigues, G.; Hoshino, A.; Kenific, C.M.; Matei, I.R.; Steiner, L.; Freitas, D.; Kim, H.S.; Oxley, P.R.; Scandariato, I.; Casanova-Salas, I.; et al. Tumour exosomal CEMIP protein promotes cancer cell colonization in brain metastasis. Nat. Cell Biol. 2019, 21, 1403-1412. [CrossRef]

20. Pein, M.; Insua-Rodríguez, J.; Hongu, T.; Riedel, A.; Meier, J.; Wiedmann, L.; Decker, K.; Essers, M.A.G.; Sinn, H.-P.; Spaich, S.; et al. Metastasis-initiating cells induce and exploit a fibroblast niche to fuel malignant colonization of the lungs. Nat. Commun. 2020, 11, 1-18. [CrossRef]

21. Fares, J.; Fares, M.Y.; Khachfe, H.H.; Salhab, H.A.; Fares, Y. Molecular principles of metastasis: A hallmark of cancer revisited. Signal Transduct. Target. Ther. 2020, 5, 1-17. [CrossRef]

22. Ross, J.B.; Huh, D.; Noble, L.B.; Tavazoie, S.F. Identification of molecular determinants of primary and metastatic tumour re-initiation in breast cancer. Nat. Cell Biol. 2015, 17, 651-664. [CrossRef]

23. Bakhoum, S.F.; Ngo, B.; Laughney, A.M.; Cavallo, J.-A.; Murphy, C.J.; Ly, P.; Shah, P.; Sriram, R.K.; Watkins, T.B.K.; Taunk, N.K.; et al. Chromosomal instability drives metastasis through a cytosolic DNA response. Nature 2018, 553, 467-472. [CrossRef]

24. Tavora, B.; Mederer, T.; Wessel, K.J.; Ruffing, S.; Sadjadi, M.; Missmahl, M.; Ostendorf, B.N.; Liu, X.; Kim, J.-Y.; Olsen, O.; et al. Tumoural activation of TLR3-SLIT2 axis in endothelium drives metastasis. Nature 2020, 586, 1-6. [CrossRef]

25. Minn, A.J.; Gupta, G.P.; Siegel, P.M.; Bos, P.D.; Shu, W.; Giri, D.D.; Viale, A.; Olshen, A.B.; Gerald, W.L.; Massagué, J. Genes that mediate breast cancer metastasis to lung. Nature 2005, 436, 518-524. [CrossRef]

26. Nakayama, J.; Ito, E.; Fujimoto, J.; Watanabe, S.; Semba, K. Comparative analysis of gene regulatory networks of highly metastatic breast cancer cells established by orthotopic transplantation and intra-circulation injection. Int. J. Oncol. 2017, 50, 497-504. [CrossRef] [PubMed]

27. Pillar, N.; Polsky, A.L.; Weissglas-Volkov, D.; Shomron, N. Comparison of breast cancer metastasis models reveals a possible mechanism of tumor aggressiveness. Cell Death Dis. 2018, 9, 1-11. [CrossRef] 
28. Ross, C.; Szczepanek, K.; Lee, M.; Yang, H.; Peer, C.J.; Kindrick, J.; Shankarappa, P.; Lin, Z.W.; Sanford, J.D.; Figg, W.D.; et al. Metastasis-Specific Gene Expression in Autochthonous and Allograft Mouse Mammary Tumor Models: Stratification and Identification of Targetable Signatures. Mol. Cancer Res. 2020, 18, 1278-1289. [CrossRef] [PubMed]

29. Mirabelli, P.; Coppola, L.; Salvatore, M. Cancer Cell Lines Are Useful Model Systems for Medical Research. Cancers 2019, 11, 1098. [CrossRef] [PubMed]

30. Gillet, J.-P.; Varma, S.; Gottesman, M.M. The Clinical Relevance of Cancer Cell Lines. J. Natl. Cancer Inst. 2013, 105, 452-458. [CrossRef]

31. Sulaiman, A.; Wang, L. Bridging the divide: Preclinical research discrepancies between triple-negative breast cancer cell lines and patient tumors. Oncotarget 2017, 8, 113269-113281. [CrossRef]

32. Shi, J.; Li, Y.; Jia, R.; Fan, X. The fidelity of cancer cells in PDX models: Characteristics, mechanism and clinical significance. Int. J. Cancer 2020, 146, 2078-2088. [CrossRef]

33. Murayama, T.; Gotoh, N. Patient-Derived Xenograft Models of Breast Cancer and Their Application. Cells 2019, 8, 621. [CrossRef]

34. Lee, M.W.; Miljanic, M.; Triplett, T.; Ramirez, C.; Aung, K.L.; Eckhardt, S.G.; Capasso, A. Current methods in translational cancer research. Cancer Metastasis Rev. 2020, 1-24. [CrossRef] [PubMed]

35. Hoffman, R.M. Patient-derived orthotopic xenografts: Better mimic of metastasis than subcutaneous xenografts. Nat. Rev. Cancer 2015, 15, 451-452. [CrossRef] [PubMed]

36. Zhang, X.; Claerhout, S.; Pratt, A.; Dobrolecki, L.E.; Petrovic, I.; Lai, Q.; Landis, M.D.; Wiechmann, L.; Schiff, R.; Giuliano, M.; et al. A Renewable Tissue Resource of Phenotypically Stable, Biologically and Ethnically Diverse, Patient-Derived Human Breast Cancer Xenograft Models. Cancer Res. 2013, 73, 4885-4897. [CrossRef] [PubMed]

37. González-González, A.; Muñoz-Muela, E.; Marchal, J.A.; Cara, F.E.; Molina, M.P.; Cruz-Lozano, M.; Jiménez, G.; Verma, A.; Ramírez, A.; Qian, W.; et al. Activating Transcription Factor 4 Modulates TGF $\beta$-Induced Aggressiveness in Triple-Negative Breast Cancer via SMAD2/3/4 and mTORC2 Signaling. Clin. Cancer Res. 2018, 24, 5697-5709. [CrossRef] [PubMed]

38. Paez-Ribes, M.; Man, S.; Xu, P.; Kerbel, R.S. Development of Patient Derived Xenograft Models of Overt Spontaneous Breast Cancer Metastasis: A Cautionary Note. PLoS ONE 2016, 11, e0158034. [CrossRef] [PubMed]

39. Oshi, M.; Okano, M.; Maiti, A.; Rashid, O.M.; Saito, K.; Kono, K.; Matsuyama, R.; Endo, I.; Takabe, K. Novel Breast Cancer Brain Metastasis Patient-Derived Orthotopic Xenograft Model for Preclinical Studies. Cancers 2020, 12, 444. [CrossRef]

40. Lefley, D.; Howard, F.; Arshad, F.; Bradbury, S.; Brown, H.; Tulotta, C.; Eyre, R.; Alférez, D.; Wilkinson, J.M.; Holen, I.; et al. Development of clinically relevant in vivo metastasis models using human bone discs and breast cancer patient-derived xenografts. Breast Cancer Res. 2019, 21, 130. [CrossRef]

41. Fujii, E.; Kato, A.; Suzuki, M. Patient-derived xenograft (PDX) models: Characteristics and points to consider for the process of establishment. J. Toxicol. Pathol. 2020, 33, 153-160. [CrossRef]

42. Van 't Veer, L.J.; Dai, H.; van de Vijver, M.J.; He, Y.D.; Hart AA, M.; Mao, M.; Peterse, H.L.; van der Kooy, K.; Marton, M.J.; Witteveen, A.T.; et al. Gene expression profiling predicts clinical outcome of breast cancer. Nature 2002, 415, 530-536. [CrossRef]

43. Sorlie, T.; Perou, C.M.; Tibshirani, R.; Aas, T.; Geisler, S.; Johnsen, H.; Hastie, T.; Eisen, M.B.; van de Rijn, M.; Jeffrey, S.S.; et al. Gene expression patterns of breast carcinomas distinguish tumor subclasses with clinical implications. Proc. Natl. Acad. Sci. USA 2001, 98, 10869-10874. [CrossRef]

44. Van de Vijver, M.J.; He, Y.D.; van ‘t Veer, L.J.; Dai, H.; Hart AA, M.; Voskuil, D.W.; Schreiber, G.J.; Peterse, J.L.; Roberts, C.; Marton, M.J.; et al. A Gene-Expression Signature as a Predictor of Survival in Breast Cancer. N. Engl. J. Med. 2002, 347, 1999-2009. [CrossRef]

45. Kang, Y.; Siegel, P.M.; Shu, W.; Drobnjak, M.; Kakonen, S.M.; Cordón-Cardo, C.; Guise, T.A.; Massagué, J. A multigenic program mediating breast cancer metastasis to bone. Cancer Cell 2003, 3, 537-549. [CrossRef]

46. Oskarsson, T.; Batlle, E.; Massagué, J. Metastatic Stem Cells: Sources, Niches, and Vital Pathways. Cell Stem Cell 2014, $14,306-321$. [CrossRef]

47. Vanharanta, S.; Massagué, J. Origins of Metastatic Traits. Cancer Cell 2013, 24, 410-421. [CrossRef]

48. Gupta, G.P.; Massagué, J. Cancer Metastasis: Building a Framework. Cell 2006, 127, 679-695. [CrossRef] [PubMed]

49. Neophytou, C.; Boutsikos, P.; Papageorgis, P. Molecular Mechanisms and Emerging Therapeutic Targets of Triple-Negative Breast Cancer Metastasis. Front. Oncol. 2018, 8, 31. [CrossRef] [PubMed]

50. Jenkins, D.E.; Hornig, Y.S.; Oei, Y.; Dusich, J.; Purchio, T. Bioluminescent human breast cancer cell lines that permit rapid and sensitive in vivo detection of mammary tumors and multiple metastases in immune deficient mice. Breast Cancer Res. 2005, 7, R444-R454. [CrossRef] [PubMed]

51. Kuchimaru, T.; Kataoka, N.; Nakagawa, K.; Isozaki, T.; Miyabara, H.; Minegishi, M.; Kadonosono, T.; Kizaka-Kondoh, S. A reliable murine model of bone metastasis by injecting cancer cells through caudal arteries. Nat. Commun. 2018, 9, 1-7. [CrossRef]

52. Goddard, E.T.; Fischer, J.; Schedin, P. A Portal Vein Injection Model to Study Liver Metastasis of Breast Cancer. J. Vis. Exp. 2016, 118, e54903. [CrossRef]

53. Zhang, C.; Lowery, F.J.; Yu, D. Intracarotid Cancer Cell Injection to Produce Mouse Models of Brain Metastasis. J. Vis. Exp. 2017, 120, 55085. [CrossRef]

54. Ozawa, T.; James, C.D. Establishing Intracranial Brain Tumor Xenografts with Subsequent Analysis of Tumor Growth and Response to Therapy using Bioluminescence Imaging. J. Vis. Exp. 2010, 41, e1986. [CrossRef] 
55. Haley, H.R.; Shen, N.; Qyli, T.; Buschhaus, J.M.; Pirone, M.; Luker, K.E.; Luker, G.D. Enhanced Bone Metastases in Skeletally Immature Mice. Tomography 2018, 4, 84-93. [CrossRef]

56. Yu, J.; Zhou, Y.; Hua, X.; Zhu, Z.; Yu, X.-Y. In Situ Characterization of Hydrated Proteins in Water by SALVI and ToF-SIMS. J. Vis. Exp. 2016, 108, e53708. [CrossRef]

57. Li, X.; Sterling, J.A.; Fan, K.H.; Vessella, R.L.; Shyr, Y.; Hayward, S.W.; Matrisian, L.M.; Bhowmick, N.A. Loss of TGF- $\beta$ responsiveness in prostate stromal cells alters chemokine levels and facilitates the development of mixed osteoblastic/osteolytic bone lesions. Mol. Cancer Res. 2012, 10, 494-503. [CrossRef]

58. Valiente, M.; Van Swearingen, A.E.; Anders, C.K.; Bairoch, A.; Boire, A.; Bos, P.D.; Cittelly, D.M.; Erez, N.; Ferraro, G.B.; Fukumura, D.; et al. Brain Metastasis Cell Lines Panel: A Public Resource of Organotropic Cell Lines. Cancer Res. 2020, 80, 4314-4323. [CrossRef]

59. Jin, X.; DeMere, Z.; Nair, K.; Ali, A.; Ferraro, G.B.; Natoli, T.; Deik, A.; Petronio, L.; A Tang, A.; Zhu, C.; et al. A metastasis map of human cancer cell lines. Nature 2020, 588, 331-336. [CrossRef]

60. Kuroiwa, Y.; Nakayama, J.; Adachi, C.; Inoue, T.; Watanabe, S.; Semba, K. Proliferative Classification of Intracranially Injected HER2-positive Breast Cancer Cell Lines. Cancers 2020, 12, 1811. [CrossRef] [PubMed]

61. Tabaries, S.; Dong, Z.; Annis, M.G.; Omeroglu, A.; Pepin, F.; Ouellet, V.; Russo, C.; Hassanain, M.; Metrakos, P.; Diaz, Z.H.; et al. Claudin-2 is selectively enriched in and promotes the formation of breast cancer liver metastases through engagement of integrin complexes. Oncogene 2011, 30, 1318-1328. [CrossRef]

62. Sasaki, S.; Baba, T.; Nishimura, T.; Hayakawa, Y.; Hashimoto, S.-I.; Gotoh, N.; Mukaida, N. Essential roles of the interaction between cancer cell-derived chemokine, CCL4, and intra-bone CCR5-expressing fibroblasts in breast cancer bone metastasis. Cancer Lett. 2016, 378, 23-32. [CrossRef] [PubMed]

63. Takahashi, M.; Furihata, M.; Akimitsu, N.; Watanabe, M.; Kaul, S.; Yumoto, N.; Okada, T. A highly bone marrow metastatic murine breast cancer model established through in vivo selection exhibits enhanced anchorage-independent growth and cell migration mediated by ICAM-1. Clin. Exp. Metastasis 2008, 25, 517-529. [CrossRef] [PubMed]

64. Erin, N.; Wang, N.; Xin, P.; Bui, V.; Weisz, J.; Barkan, G.A.; Zhao, W.; Shearer, D.; Clawson, G.A. Altered gene expression in breast cancer liver metastases. Int. J. Cancer 2009, 124, 1503-1516. [CrossRef] [PubMed]

65. Lala, P.K.; Parhar, R.S. Eradication of spontaneous and experimental adenocarcinoma metastases with chronic indomethacin and intermittent IL-2 therapy. Int. J. Cancer 1993, 54, 677-684. [CrossRef]

66. Tavazoie, S.F.; Alarcón, C.; Oskarsson, T.; Padua, D.; Wang, Q.; Bos, P.D.; Gerald, W.L.; Massagué, J. Endogenous human microRNAs that suppress breast cancer metastasis. Nature 2008, 451, 147-152. [CrossRef]

67. Han, Y.; Nakayama, J.; Hayashi, Y.; Jeong, S.; Futakuchi, M.; Ito, E.; Watanabe, S.; Semba, K. Establishment and characterization of highly osteolytic luminal breast cancer cell lines by intracaudal arterial injection. Genes Cells 2020, 25, 111-123. [CrossRef]

68. Jiang, H.-L.; Sun, H.-F.; Gao, S.-P.; Li, L.-D.; Hu, X.; Wu, J.; Jin, W. Loss of RAB1B promotes triple-negative breast cancer metastasis by activating TGF- $\beta$ /SMAD signaling. Oncotarget 2015, 6, 16352-16365. [CrossRef]

69. Fietz, E.R.; Keenan, C.R.; López-Campos, G.; Tu, Y.; Johnstone, C.N.; Harris, T.; Stewart, A.G. Glucocorticoid resistance of migration and gene expression in a daughter MDA-MB-231 breast tumour cell line selected for high metastatic potential. Sci. Rep. 2017, 7, 43774. [CrossRef]

70. Chang, X.-Z.; Li, D.-Q.; Hou, Y.-F.; Wu, J.; Lu, J.-S.; Di, G.-H.; Jin, W.; Ou, Z.-L.; Shen, Z.-Z.; Shao, Z.-M. Identification of the functional role of AF1Q in the progression of breast cancer. Breast Cancer Res. Treat. 2008, 111, 65-78. [CrossRef]

71. Li, D.-Q.; Wang, L.; Fei, F.; Hou, Y.-F.; Luo, J.-M.; Chen, W.; Zeng, R.; Wu, J.; Lu, J.-S.; Di, G.-H.; et al. Identification of breast cancer metastasis-associated proteins in an isogenic tumor metastasis model using two-dimensional gel electrophoresis and liquid chromatography-ion trap-mass spectrometry. Proteomics 2006, 6, 3352-3368. [CrossRef]

72. Vantyghem, S.A.; Allan, A.L.; Postenka, C.O.; Al-Katib, W.; Keeney, M.; Tuck, A.B.; Chambers, A.F. A new model for lymphatic metastasis: Development of a variant of the MDA-MB-468 human breast cancer cell line that aggressively metastasizes to lymph nodes. Clin. Exp. Metastasis 2005, 22, 351-361. [CrossRef]

73. Kim, H.; Kim, B.; Kim, S.I.; Kim, H.J.; Ryu, B.Y.; Chung, J.; Lee, Z.H.; Kim, H.-H. S100A4 released from highly bone-metastatic breast cancer cells plays a critical role in osteolysis. Bone Res. 2019, 7, 1-13. [CrossRef]

74. Esposito, M.; Mondal, N.; Greco, T.M.; Wei, Y.; Spadazzi, C.; Lin, S.C.; Zheng, H.; Cheung, C.; Magnani, J.L.; Lin, S.H.; et al. Bone vascular niche E-selectin induces mesenchymal-epithelial transition and Wnt activation in cancer cells to promote bone metastasis. Nat. Cell Biol. 2019, 21, 627-639. [CrossRef]

75. Johnstone, C.N.; Pattison, A.D.; Gorringe, K.L.; Harrison, P.F.; Powell, D.R.; Lock, P.; Baloyan, D.; Ernst, M.; Stewart, A.G.; Beilharz, T.H.; et al. Functional and genomic characterisation of a xenograft model system for the study of metastasis in triplenegative breast cancer. Dis. Models Mech. 2018, 11, dmm032250. [CrossRef] [PubMed]

76. Oskarsson, T.; Acharyya, S.; Zhang, X.H.-F.; Vanharanta, S.; Tavazoie, S.F.; Morris, P.G.; Downey, R.J.; Manova-Todorova, K.; Brogi, E.; Massagué, J. Breast cancer cells produce tenascin C as a metastatic niche component to colonize the lungs. Nat. Med. 2011, 17, 867-874. [CrossRef]

77. Song, K.-H.; Park, M.S.; Nandu, T.S.; Gadad, S.; Kim, S.-C.; Kim, M.-Y. GALNT14 promotes lung-specific breast cancer metastasis by modulating self-renewal and interaction with the lung microenvironment. Nat. Commun. 2016, 7, 13796. [CrossRef] [PubMed]

78. Liu, L.; Yin, B.; Yi, Z.; Liu, X.; Hu, Z.; Gao, W.; Yu, H.; Li, Q. Breast cancer stem cells characterized by CD70 expression preferentially metastasize to the lungs. Breast Cancer 2018, 25, 706-716. [CrossRef] 
79. Wu, J.; Jiang, Z.; Chen, C.; Hu, Q.; Fu, Z.; Chen, J.; Wang, Z.; Wang, Q.; Li, A.; Marks, J.R.; et al. CircIRAK3 sponges miR-3607 to facilitate breast cancer metastasis. Cancer Lett. 2018, 430, 179-192. [CrossRef]

80. Hiraga, T. Bone metastasis: Interaction between cancer cells and bone microenvironment. J. Oral Biosci. 2019, 61, 95-98. [CrossRef]

81. Esposito, M.; Kang, Y. Targeting tumor-stromal interactions in bone metastasis. Pharmacol. Ther. 2014, 141, 222-233. [CrossRef] [PubMed]

82. Mundy, G.R. Metastasis to bone: Causes, consequences and therapeutic opportunities. Nat. Rev. Cancer 2002, 2, 584-593. [CrossRef] [PubMed]

83. Khanna, C.; Hunter, K. Modeling metastasis in vivo. Carcinogenesis 2005, 26, 513-523. [CrossRef]

84. Simmons, J.K.; Hildreth, B.E., 3rd; Supsavhad, W.; Elshafae, S.M.; Hassan, B.B.; Dirksen, W.P.; Toribio, R.E.; Rosol, T.J. Animal Models of Bone Metastasis. Vet. Pathol. 2015, 52, 827-841. [CrossRef] [PubMed]

85. Allinen, M.; Beroukhim, R.; Cai, L.; Brennan, C.; Lahti-Domenici, J.; Huang, H.; Porter, D.; Hu, M.; Chin, L.; Richardson, A.; et al. Molecular characterization of the tumor microenvironment in breast cancer. Cancer Cell 2004, 6, 17-32. [CrossRef] [PubMed]

86. Eck, S.M.; Hoopes, P.J.; Petrella, B.L.; Coon, C.I.; Brinckerhoff, C.E. Matrix metalloproteinase-1 promotes breast cancer angiogenesis and osteolysis in a novel in vivo model. Breast Cancer Res. Treat. 2009, 116, 79-90. [CrossRef]

87. Zhuang, X.; Zhang, H.; Li, X.; Li, X.; Cong, M.; Peng, F.; Yu, J.; Zhang, X.; Yang, Q.; Hu, G. Differential effects on lung and bone metastasis of breast cancer by Wnt signalling inhibitor DKK1. Nat. Cell Biol. 2017, 19, 1274-1285. [CrossRef]

88. Nayak, L.; Lee, E.Q.; Wen, P.Y. Epidemiology of Brain Metastases. Curr. Oncol. Rep. 2012, 14, 48-54. [CrossRef]

89. Lim, M.; Puttick, S.; Houston, Z.H.; Thurecht, K.J.; Croft, P.K.-D.; Mahler, S.; Rose, S.E.; Jeffree, R.L.; Mazzieri, R.; Dolcetti, R.; et al. Innovative Therapeutic Strategies for Effective Treatment of Brain Metastases. Int. J. Mol. Sci. 2019, 20, 1280. [CrossRef]

90. Lin, X.; DeAngelis, L.M. Treatment of Brain Metastases. J. Clin. Oncol. 2015, 33, 3475-3484. [CrossRef]

91. Bos, P.D.; Zhang, X.H.-F.; Nadal, C.; Shu, W.; Gomis, R.R.; Nguyen, D.X.; Minn, A.J.; Van De Vijver, M.J.; Gerald, W.L.; Foekens, J.A.; et al. Genes that mediate breast cancer metastasis to the brain. Nature 2009, 459, 1005-1009. [CrossRef] [PubMed]

92. Liu, Z.; Wang, Y.; Kabraji, S.; Xie, S.; Pan, P.; Liu, Z.; Ni, J.; Zhao, J.J. Improving orthotopic mouse models of patient-derived breast cancer brain metastases by a modified intracarotid injection method. Sci. Rep. 2019, 9, 622. [CrossRef] [PubMed]

93. Priego, N.; Zhu, L.; Monteiro, C.; Mulders, M.; Wasilewski, D.; Bindeman, W.; Doglio, L.; Martínez-Saez, E.; Cajal, S.R.Y.; Fustero-Torre, C.; et al. Abstract 2746: Stat3 labels a subpopulation of reactive astrocytes required for brain metastasis. Tumor Biol. 2019, 24, 1024-1035. [CrossRef]

94. Wyatt, E.A.; Davis, M.E. Method of establishing breast cancer brain metastases affects brain uptake and efficacy of targeted, therapeutic nanoparticles. Bioeng. Transl. Med. 2018, 4, 30-37. [CrossRef]

95. Sevenich, L.; Bowman, R.L.; Mason, S.D.; Quail, D.F.; Rapaport, F.; Elie, B.T.; Brogi, E.; Brastianos, P.K.; Hahn, W.C.; Holsinger, L.J.; et al. Analysis of tumour- and stroma-supplied proteolytic networks reveals a brain-metastasis-promoting role for cathepsin S. Nat. Cell Biol. 2014, 16, 876-888. [CrossRef] [PubMed]

96. Valiente, M.; Obenauf, A.C.; Jin, X.; Chen, Q.; Zhang, X.H.-F.; Lee, D.J.; Chaft, J.E.; Kris, M.G.; Huse, J.T.; Brogi, E.; et al. Serpins Promote Cancer Cell Survival and Vascular Co-Option in Brain Metastasis. Cell 2014, 156, 1002-1016. [CrossRef]

97. Zeng, Q.; Michael, I.P.; Zhang, P.; Saghafinia, S.; Knott, G.; Jiao, W.; McCabe, B.D.; Galván, J.A.; Robinson, H.P.C.; Zlobec, I.; et al. Synaptic proximity enables NMDAR signalling to promote brain metastasis. Nature 2019, 573, 526-531. [CrossRef] [PubMed]

98. Chen, Q.; Boire, A.; Jin, X.; Valiente, M.; Er, E.E.; Lopez-Soto, A.; Jacob, L.S.; Patwa, R.; Shah, H.; Xu, K.; et al. Carcinoma-astrocyte gap junctions promote brain metastasis by cGAMP transfer. Nature 2016, 533, 493-498. [CrossRef]

99. Tominaga, N.; Kosaka, N.; Ono, M.; Katsuda, T.; Yoshioka, Y.; Tamura, K.; Lotvall, J.; Nakagama, H.; Ochiya, T. Brain metastatic cancer cells release microRNA-181c-containing extracellular vesicles capable of destructing blood-brain barrier. Nat. Commun. 2015, 6, 6716. [CrossRef]

100. Niwińska, A.; Murawska, M.; Pogoda, K. Breast cancer brain metastases: Differences in survival depending on biological subtype, RPA RTOG prognostic class and systemic treatment after whole-brain radiotherapy (WBRT). Ann. Oncol. 2010, 21, 942-948. [CrossRef] [PubMed]

101. Gril, B.; Palmieri, D.; Bronder, J.L.; Herring, J.M.; Vega-Valle, E.; Feigenbaum, L.; Liewehr, D.J.; Steinberg, S.M.; Merino, M.J.; Rubin, S.D.; et al. Effect of Lapatinib on the Outgrowth of Metastatic Breast Cancer Cells to the Brain. J. Natl. Cancer Inst. 2008, 100, 1092-1103. [CrossRef] [PubMed]

102. Palmieri, D.; Bronder, J.L.; Herring, J.M.; Yoneda, T.; Weil, R.J.; Stark, A.M.; Kurek, R.; Vega-Valle, E.; Feigenbaum, L.; Halverson, D.; et al. Her-2 overexpression increases the metastatic outgrowth of breast cancer cells in the brain. Cancer Res. 2007, 67, 4190-4198. [CrossRef] [PubMed]

103. Chen, Y.; Jiang, T.; Zhang, H.; Gou, X.; Han, C.; Wang, J.; Chen, A.T.; Ma, J.; Liu, J.; Chen, Z.; et al. LRRC31 inhibits DNA repair and sensitizes breast cancer brain metastasis to radiation therapy. Nat. Cell Biol. 2020, 22, 1276-1285. [CrossRef]

104. Gril, B.; Palmieri, D.; Qian, Y.; Smart, D.; Ileva, L.; Liewehr, D.J.; Steinberg, S.M.; Steeg, P.S. Pazopanib Reveals a Role for Tumor Cell B-Raf in the Prevention of HER2+ Breast Cancer Brain Metastasis. Clin. Cancer Res. 2011, 17, 142-153. [CrossRef]

105. Beyer, I.; Li, Z.; Persson, J.; Liu, Y.; Van Rensburg, R.; Yumul, R.; Zhang, X.-B.; Hung, M.-C.; Lieber, A. Controlled Extracellular Matrix Degradation in Breast Cancer Tumors Improves Therapy by Trastuzumab. Mol. Ther. 2011, 19, 479-489. [CrossRef] [PubMed] 
106. Lee, C.; Dhillon, J.; Wang, M.Y.; Gao, Y.; Hu, K.; Park, E.; Astanehe, A.; Hung, M.-C.; Eirew, P.; Eaves, C.J.; et al. Targeting YB-1 in HER-2 Overexpressing Breast Cancer Cells Induces Apoptosis via the mTOR/STAT3 Pathway and Suppresses Tumor Growth in Mice. Cancer Res. 2008, 68, 8661-8666. [CrossRef] [PubMed]

107. Zhang, S.; Huang, W.-C.; Zhang, L.; Zhang, C.; Lowery, F.J.; Ding, Z.; Guo, H.; Wang, H.; Huang, S.; Sahin, A.A.; et al. Src Family Kinases as Novel Therapeutic Targets to Treat Breast Cancer Brain Metastases. Cancer Res. 2013, 73, 5764-5774. [CrossRef] [PubMed]

108. Sirkisoon, S.R.; Carpenter, R.L.; Rimkus, T.; Doheny, D.; Zhu, D.; Aguayo, N.R.; Xing, F.; Chan, M.; Ruiz, J.; Metheny-Barlow, L.J.; et al. TGLI1 transcription factor mediates breast cancer brain metastasis via activating metastasis-initiating cancer stem cells and astrocytes in the tumor microenvironment. Oncogene 2020, 39, 64-78. [CrossRef]

109. Xing, F.; Liu, Y.; Sharma, S.; Wu, K.; Chan, M.D.; Lo, H.-W.; Carpenter, R.L.; Metheny-Barlow, L.J.; Zhou, X.; Qasem, S.A.; et al. Activation of the c-Met Pathway Mobilizes an Inflammatory Network in the Brain Microenvironment to Promote Brain Metastasis of Breast Cancer. Cancer Res. 2016, 76, 4970-4980. [CrossRef]

110. Lyle, L.T.; Lockman, P.R.; Adkins, C.E.; Mohammad, A.S.; Sechrest, E.; Hua, E.; Palmieri, D.; Liewehr, D.J.; Steinberg, S.M.; Kloc, W.; et al. Alterations in Pericyte Subpopulations Are Associated with Elevated Blood-Tumor Barrier Permeability in Experimental Brain Metastasis of Breast Cancer. Clin. Cancer Res. 2016, 22, 5287-5299. [CrossRef]

111. Murrell, D.H.; Hamilton, A.M.; Mallett, C.L.; Van Gorkum, R.; Chambers, A.F.; Foster, P.J. Understanding Heterogeneity and Permeability of Brain Metastases in Murine Models of HER2-Positive Breast Cancer Through Magnetic Resonance Imaging: Implications for Detection and Therapy. Transl. Oncol. 2015, 8, 176-184. [CrossRef]

112. Palmieri, D.; Duchnowska, R.; Woditschka, S.; Hua, E.; Qian, Y.; Biernat, W.; Sosińska-Mielcarek, K.; Gril, B.; Stark, A.M.; Hewitt, S.M.; et al. Profound Prevention of Experimental Brain Metastases of Breast Cancer by Temozolomide in an MGMTDependent Manner. Clin. Cancer Res. 2014, 20, 2727-2739. [CrossRef]

113. Tanaka, Y.; Hirata, M.; Shinonome, S.; Torii, M.; Nezasa, K.-I.; Tanaka, H. Distribution analysis of epertinib in brain metastasis of HER2-positive breast cancer by imaging mass spectrometry and prospect for antitumor activity. Sci. Rep. 2018, 8, 343. [CrossRef]

114. Erin, N.; Kale, S.; Tanrı̈ver, G.; Köksoy, S.; Duymuş, O.; Korcum, A.F. Differential characteristics of heart, liver, and brain metastatic subsets of murine breast carcinoma. Breast Cancer Res. Treat. 2013, 139, 677-689. [CrossRef]

115. Gao, H.; Chakraborty, G.; Zhang, Z.; Akalay, I.; Gadiya, M.; Gao, Y.; Sinha, S.; Hu, J.; Jiang, C.; Akram, M.; et al. Multi-organ Site Metastatic Reactivation Mediated by Non-canonical Discoidin Domain Receptor 1 Signaling. Cell 2016, 166, 47-62. [CrossRef]

116. Selzner, M.; Morse, M.A.; Vredenburgh, J.J.; Meyers, W.C.; Clavien, P.-A. Liver metastases from breast cancer: Long-term survival after curative resection. Surgery 2000, 127, 383-389. [CrossRef] [PubMed]

117. Adam, R.; Aloia, T.; Krissat, J.; Bralet, M.-P.; Paule, B.; Giacchetti, S.; Delvart, V.; Azoulay, D.; Bismuth, H.; Castaing, D. Is Liver Resection Justified for Patients with Hepatic Metastases from Breast Cancer? Ann. Surg. 2006, 244, 897-908. [CrossRef]

118. Ma, R.; Feng, Y.; Lin, S.; Chen, J.; Lin, H.; Liang, X.; Zheng, H.; Cai, X. Mechanisms involved in breast cancer liver metastasis. J. Transl. Med. 2015, 13, 64. [CrossRef] [PubMed]

119. Chang, X.Z.; Li, D.Q.; Hou, Y.F.; Wu, J.; Lu, J.S.; Di, G.H.; Jin, W.; Ou, Z.L.; Shen, Z.Z.; Shao, Z.M. Identification of the functional role of peroxiredoxin 6 in the progression of breast cancer. Breast Cancer Res. 2007, 9, R76. [CrossRef]

120. Tu, Y.; Johnstone, C.N.; Ryall, J.G.; López-Campos, G.H.; Keenan, C.R.; Stewart, A.G. Altered energy metabolism and metabolic gene expression associated with increased metastatic capacity identified in MDA-MB-231 cell line variants. J. Cancer Metastasis Treat. 2018, 2018, 58. [CrossRef]

121. Petrova, T.V.; Koh, G.Y. Biological functions of lymphatic vessels. Science 2020, 369, eaax4063. [CrossRef]

122. Yano, S.; Takehara, K.; Miwa, S.; Kishimoto, H.; Tazawa, H.; Urata, Y.; Kagawa, S.; Bouvet, M.; Fujiwara, T.; Hoffman, R.M. In Vivo Isolation of a Highly-aggressive Variant of Triple-negative Human Breast Cancer MDA-MB-231 Using Serial Orthotopic Transplantation. Anticancer Res. 2016, 36, 3817-3820. [CrossRef]

123. Goldhirsch, A.; Wood, W.C.; Coates, A.S.; Gelber, R.D.; Thurlimann, B.; Senn, H.J.; Panel, M. Strategies for subtypes-dealing with the diversity of breast cancer: Highlights of the St. Gallen International Expert Consensus on the Primary Therapy of Early Breast Cancer 2011. Ann. Oncol. 2011, 22, 1736-1747. [CrossRef]

124. Chen, W.; Hoffmann, A.D.; Liu, H.; Liu, X. Organotropism: New insights into molecular mechanisms of breast cancer metastasis. NPJ Precis. Oncol. 2018, 2, 4. [CrossRef]

125. Buonomo, O.C.; Caredda, E.; Portarena, I.; Vanni, G.; Orlandi, A.; Bagni, C.; Petrella, G.; Palombi, L.; Orsaria, P. New insights into the metastatic behavior after breast cancer surgery, according to well-established clinicopathological variables and molecular subtypes. PLoS ONE 2017, 12, e0184680. [CrossRef]

126. Kennecke, H.; Yerushalmi, R.; Woods, R.; Cheang, M.C.U.; Voduc, D.; Speers, C.H.; Nielsen, T.O.; Gelmon, K. Metastatic Behavior of Breast Cancer Subtypes. J. Clin. Oncol. 2010, 28, 3271-3277. [CrossRef]

127. Xiao, W.; Zheng, S.; Yang, A.; Zhang, X.; Zou, Y.; Tang, H.; Xie, X. Breast cancer subtypes and the risk of distant metastasis at initial diagnosis: A population-based study. Cancer Manag. Res. 2018, 10, 5329-5338. [CrossRef]

128. Smid, M.; Wang, Y.; Zhang, Y.; Sieuwerts, A.M.; Yu, J.; Klijn, J.G.M.; Foekens, J.A.; Martens, J.W.M. Subtypes of Breast Cancer Show Preferential Site of Relapse. Cancer Res. 2008, 68, 3108-3114. [CrossRef]

129. Wu, Q.; Li, J.; Zhu, S.; Wu, J.; Chen, C.; Liu, Q.; Wei, W.; Zhang, Y.; Sun, S. Breast cancer subtypes predict the preferential site of distant metastases: A SEER based study. Oncotarget 2017, 8, 27990-27996. [CrossRef] 
130. Gong, Y.; Liu, Y.-R.; Ji, P.; Hu, X.; Shao, Z.-M. Impact of molecular subtypes on metastatic breast cancer patients: A SEER population-based study. Sci. Rep. 2017, 7, 45411. [CrossRef] [PubMed]

131. Liu, X.H.; Rose, D.P. Differential expression and regulation of cyclooxygenase- 1 and -2 in two human breast cancer cell lines. Cancer Res. 1996, 56, 5125-5127. [PubMed]

132. Tan, C.-C.; Li, G.-X.; Tan, L.-D.; Du, X.; Li, X.-Q.; He, R.; Wang, Q.-S.; Feng, Y.-M. Breast cancer cells obtain an osteomimetic feature via epithelial-mesenchymal transition that have undergone BMP2/RUNX2 signaling pathway induction. Oncotarget 2016, 7, 79688-79705. [CrossRef]

133. Comşa, Ş.; Cimpean, A.M.; Raica, M. The Story of MCF-7 Breast Cancer Cell Line: 40 years of Experience in Research. Anticancer Res. 2015, 35, 3147-3154. [PubMed]

134. Gerratana, L.; Fanotto, V.; Bonotto, M.; Bolzonello, S.; Minisini, A.M.; Fasola, G.; Puglisi, F. Pattern of metastasis and outcome in patients with breast cancer. Clin. Exp. Metastasis 2015, 32, 125-133. [CrossRef]

135. Perou, C.M.; Sørlie, T.; Eisen, M.B.; van de Rijn, M.; Jeffrey, S.S.; Rees, C.A.; Pollack, J.R.; Ross, D.T.; Johnsen, H.; Akslen, L.A.; et al. Molecular portraits of human breast tumours. Nature 2000, 406, 747-752. [CrossRef] [PubMed]

136. Koboldt, D.C.; Fulton, R.S.; McLellan, M.D.; Schmidt, H.; Kalicki-Veizer, J.; McMichael, J.F.; Fulton, L.L.; Dooling, D.J.; Ding, L.; Mardis, E.R.; et al. Comprehensive molecular portraits of human breast tumours. Nature 2012, 490, 61-70. [CrossRef]

137. Curtis, C.; METABRIC Group; Shah, S.P.; Chin, S.-F.; Turashvili, G.; Rueda, O.M.; Dunning, M.J.; Speed, D.; Lynch, A.G.; Samarajiwa, S.; et al. The genomic and transcriptomic architecture of 2000 breast tumours reveals novel subgroups. Nature 2012, 486, 346-352. [CrossRef]

138. Pereira, B.; Chin, S.-F.; Rueda, O.M.; Vollan, H.-K.M.; Provenzano, E.; Bardwell, H.A.; Pugh, M.; Jones, L.A.; Russell, R.; Sammut, S.-J.; et al. The somatic mutation profiles of 2,433 breast cancers refine their genomic and transcriptomic landscapes. Nat. Commun. 2016, 7, 11479. [CrossRef]

139. Ali, H.R.; Team, C.I.G.C.; Jackson, H.W.; Zanotelli, V.R.T.; Danenberg, E.; Fischer, J.R.; Bardwell, H.; Provenzano, E.; Rueda, O.M.; Chin, S.-F.; et al. Imaging mass cytometry and multiplatform genomics define the phenogenomic landscape of breast cancer. Nat. Rev. Cancer 2020, 1, 163-175. [CrossRef]

140. Yates, L.R.; Knappskog, S.; Wedge, D.; Farmery, J.H.; Gonzalez, S.; Martincorena, I.; Alexandrov, L.B.; Van Loo, P.; Haugland, H.K.; Lilleng, P.K.; et al. Genomic Evolution of Breast Cancer Metastasis and Relapse. Cancer Cell 2017, 32, 169-184.e7. [CrossRef]

141. Chen, R.; Goodison, S.; Sun, Y. Molecular Profiles of Matched Primary and Metastatic Tumor Samples Support a Linear Evolutionary Model of Breast Cancer. Cancer Res. 2020, 80, 170-174. [CrossRef]

142. Robinson, D.R.; Wu, Y.-M.; Lonigro, R.J.; Vats, P.; Cobain, E.; Everett, J.; Cao, X.; Rabban, E.; Kumar-Sinha, C.; Raymond, V.; et al. Integrative clinical genomics of metastatic cancer. Nature. 2017, 548, 297-303. [CrossRef]

143. Quinn, J.J.; Jones, M.G.; Okimoto, R.A.; Nanjo, S.; Chan, M.M.; Yosef, N.; Bivona, T.G.; Weissman, J.S. Single-cell lineages reveal the rates, routes, and drivers of metastasis in cancer xenografts. Science 2021, eabc1944. [CrossRef] [PubMed] 